4. Kosareva, K. (2012). Under the sign of the wind. Tribuna molodogo zhurnalista, [online] 2 (118). Available at: http://tribuna.mosconsv.ru/?p=3289 [Accessed 27 February 2019] [in Russian].

5. Nazaykinskiy, E. (1972). About the psychology of musical perception. Moscow: Muzyka [in Russian].

6. Rudnev, V. (2001). Encyclopedic dictionary of culture of the twentieth century. Moscow: Agraf [in Russian].

7. Snitkova, I. (1991). The sound material of modern music and some aspects of the theory of texture. Faktura v sisteme muzykalno-vyrazitelnyh sredstv. Krasnoyarsk [in Russian].

8. Tsenova, V. (Ed.) (2005). Theory of modern composition. Moscow: Muzyka [in Russian].

9. Holopova, V. (2001). Forms of musical compositions. Saint Petersburg: Lan [in Russian].

10. Griffiths, P. (2010). Modern music and After. 3-d ed. New York: Oxford University Press [in English].

УДК 78.071.1(479.25)78.03"19":78.082

DOI: https://doi.org/10.33643/kmus.2019.58.06

Маріам Вердіян,
аспірант кафедри теорї̈музики
Національної музичної академії України ім. П. I. Чайковського
https://orcid.org/0000-0003-2835-0021
m.verdiian@gmail.com
Mariam Verdiian,
Postgraduate at the Department of Music Theory,
Ukrainian National Tchaikovsky Academy of Music
https://orcid.org/0000-0003-2835-0021
m.verdiian@gmail.com

\title{
ОДНОЧАСТИННІ СИМФОНІї АВЕТА ТЕРТЕРЯНА: КОМПОЗИЦІЙНО-ДРАМАТУРГІЧНІ АСПЕКТИ (НА ПРИКЛАДІ П'ЯТОЇ ТА ШОСТОЇ СИМФОНІЙ)
}

Розглянуто особливості симфонічного стилю А. Тертеряна на прикладі його одночастинних симфоній. Проаналізовано драматургічні та композиційні параметри П'ятої та Шостої симфоній. Сонорика, алеаторика та мікрохроматика визначені як основні композиторські техніки в побудові композиційного профілю творів. П’яту симфонію проаналізовано 3 урахуванням специфіки втілення східного відчуття звуку. Встановлено значення монодичної традиції як стрижневого формоутворюючого фактора та основи драматургічного розгортання матеріалу.

У концепції Шостої симфонії виявлено зв'язок із семантичним ядром реквієму. Визначено, що музика не успадковує структурних моделей жанру, але композитор зберігає в ній смислові коди заупокійної меси. 
Досліджено принципи відтворення архаїчних символів національної культури через використання фонем старовірменської лексики.

Ключові слова: вірменська симфонічна музика XX століття, одночастинна симфонія, Авет Тертерян, П'ята симфонія, Шоста симфонія, монодія, реквієм.

Verdiian Mariam. One-movement symphonies of Avet Terteryan: compositional and dramatic aspects (on the example of the Fifth and Sixth Symphonies). The research objective is determined the peculiarities of the composition and dramaturgical organization of the Fifth and Sixth Symphonies of A. Terteryan, taking into account the specificity of the pivotal-volume structure of the material. To solve this goal, is selected the structural-functional method of analysis.

The main feature of Terteryan's creative work is synthesized - a synthesis of the technical arsenal of linguistic innovations of the twentieth century with deep, archaic layer of internal culture - and it is defined as an innovative idea of the composer. Dramaturgical and compositional parameters of the Fifth and Sixth Symphonies are analyzed. Sonorism, aleatoric and microchromatic are defined as the main composer techniques in the construction of the compositional profile of the work.

Concept of the Fifth Symphony taking into account the specific embodiments of the eastern sound sensations is analyzed. The value of monodic tradition as a pivotal factor shaping and basics of dramatic material deployment is installed. The principles of reconstruction of national musical language through creative reconstruction of archaic symbols and signs of the Armenian monody is studied.

A connection was found in the concept of the Sixth Symphony with the semantic core of the requiem. It is determined that music does not inherit structural models of the genre and is free from church regulations, but the composer retains the semantic codes of the funeral mass. The peculiarities of the musical symbols of the spiritual genres, to which the composer appeals in the symphony, is established. The principles of reproduction of archaic symbols of national culture through the use of the phoneme of old-Armenian alphabet is researched.

Key words: Armenian symphonic music of the twentieth century, onemovement symphony, Avet Terteryan, Fifth Symphony, Sixth Symphony, monody, requiem.

Вердиян Мариам. Одночастные симфонии Авета Тертеряна: композиционно-драматургические аспекты (на примере Пятой и Шестой симфоний). Задачей исследования являлся анализ особенностей 
композиционно-драматургической организации Пятой и Шестой симфоний А. Тертеряна с учетом специфики звуковысотной структуры материала. Для решения поставленной цели избран структурнофункциональный метод анализа.

Рассмотрены особенности симфонического стиля А. Тертеряна на примере его одночастных симфоний. Основная черта творчества Тертеряна - синтез технического арсенала языковых новаций XX века с глубинными, архаичными пластами отечественной культуры - определена как новаторская идея композитора. Проанализированы драматургические и композиционные параметры Пятой и Шестой симфоний. Сонорика, алеаторика и микрохроматика определены как основные композиторские техники в построении композиционного профиля произведения.

Концепция Пятой симфонии рассматривается с учетом специфики воплощения восточного ощущения звука. Установлено значение монодической традиции как стержневого формообразующего фактора и основы драматургического развертывания материала. Исследованы принципы воссоздания национального музыкального языка через творческую реконструкцию архаических символов и знаков армянской монодии.

В концепции Шестой симфонии выявлена связь с семантическим ядром реквиема. Определено, что музыка не наследует структурные модели жанра и свободна от церковных регламентов, но композитор сохраняет в ней смысловые коды заупокойной мессы. Установлены особенности музыкальной символики духовных жанров, к которым апеллирует композитор в симфонии. Исследованы принципы воспроизведения архаичных символов национальной культуры через использование фонем староармянской лексики.

Ключевые слова: армянская симфоническая музыка ХX века, одночастная симфония, Авет Тертерян, Пятая симфония, Шестая симфония, монодия, реквием.

Bcmyn. Творчість Авета Тертеряна стала однією з яскравих сторінок сучасної антології вірменського музичного мистецтва. Вона уособлює синтез високої композиторської майстерності, володіння багатим арсеналом мовних новацій ХХ століття 3 глибинними, архаїчними пластами вітчизняної культури. Тяжіння композитора до новаторства відображене в усіх сферах його творчості, особливо - у симфонічній. Автор восьми симфоній став продовжувачем національної історії жанру та водночас - руйнівником встановлених канонів. 
На сьогоднішній день існує чимало досліджень, присвячених музиці А. Тертеряна, проте в більшості 3 них не зачіпається проблематика композиційно-драматургічної логіки побудови його одночастинних симфоній. Недостатня розробленість поставленої проблеми в музикознавчих джерелах, а також звернення до симфонічних творів сучасного автора зумовлюють актуальність даного ракурсу дослідження.

Mema cmammi - виявити особливості композиційно-драматургічної організації одночастинних симфоній А. Тертеряна 3 урахуванням специфіки звуковисотної структури матеріалу.

У зв'язку з обраною метою роботи було визначено наступні завдання:

1) виявити основні риси симфонічного стилю А. Тертеряна в контексті традицій розвитку жанру;

2) встановити особливості побудови одночастинних симфоній композитора;

3) проаналізувати драматургічні та композиційні параметри П'ятої та Шостої симфоній А. Тертеряна.

Професійна музична зацікавленість постаттю Авета Тертеряна, різноманітними ракурсами його творчої спадщини активно формує цілий корпус наукових публікацій не лише вірменських, а й вітчизняних дослідників. Музикознавча література на сьогоднішній день достатньо багата на інформаційний та аналітичний матеріал про композитора та його музику: монографія (М. Рухкян «Авет Тертерян. Творчість та життя», 1996 [6]), документальний збірник (Р. Тертерян «Авет Тертерян. Діалоги», 2010 [8]), дисертації, у яких музика А. Тертеряна $\epsilon$ ілюстрацією до розробки більш широко поставленої теоретичної проблеми (роботи М. Кузнецової [3], І. Ковбас [2], Л. Птушко [5]), ряд статей наукового та публіцистичного характеру.

Але в більшості музикознавчих робіт симфонічна творчість А. Тертеряна практично не вивчається в контексті композиційнодраматургічних особливостей, які виникають в результаті взаємодії специфічних сонорно-алеаторних принципів організації матеріалу, їхнього впливу на індивідуальний профіль формування цілісності, що є фактором новизни обраного нами ракурсу дослідження.

Методи дослідження. Необхідність багатостороннього розгляду об’єкту дослідження зумовила появу комплексного підходу. У його основі - поєднання елементів:

- історичного методу - при вивченні загальної панорами симфонічної творчості А. Тертеряна; 
- методу структурно-функційного аналізу - при вивченні композиційно-драматургічної організації П'ятої та Шостої симфоній;

- методу порівняльного аналізу - при виявленні та співставленні специфічних рис П'ятої та Шостої симфоній.

Результати. П'ята симфонія (1978) стала у творчості А. Тертеряна втіленням особливого східного сприйняття Звуку - неспішного вслуховування в його глибину, усвідомлення його багатомірності, символічності, цілісності.

Концепція П'ятої симфонії реалізується в опозиції просторово-часової організації твору, яка виражається в діалектичній парі дієвості та медитативності. У П'ятій симфонії медитація набуває етнічного забарвлення за допомогою реконструкції в ній національних архаїчних символів, витоків і внаслідок цього позбавляється ознак універсалізації. Тому композитор звертається до національного інструменту 3 дуже специфічним тембром - кяманчі ${ }^{1}$. Як і в інших симфоніях, де А. Тертерян використовує в симфонічному оркестрі натуральне звучання вірменських народних інструментів, даному тембру він доручає важливу, функціонально значущу роль - у ньому як би звучить голос композитора, авторське «я».

Композиція П'ятої симфонії є «спаяним» драматургічним полотном, неподільним на частини, без чітких «цезур» і свідомо артикульованих структурних меж. Проте умовно іiі можна розмежувати на розділи, які відповідають певним фазам драматургічного «проростання» матеріалу. У симфонії чотири фази.

Первинним імпульсом твору, з якого проростає інтонаційна енергія композиції, є одиничний звук. Навіть більше, цей одиничний звук $\epsilon$ смисловим центром у «медитативних» фазах твору, а саме - у першій та третій, де «слово» передається кяманчі.

Перша фаза симфонії за своєю природою монодична. Логіка іiі розвитку будується на визріванні з найдрібнішої одиниці - точки as усієї звукової матерії, що має свою внутрішню сонорну динаміку. Основним композиційним рушієм фази є поступове широтне потовщення звукового поля, де кожний новий елемент чи цілий комплекс елементів нарощується на звук as.

А. Тертерян втілює у першій фазі творчо реконструйовані принципи вірменської монодії, які відтворюють стан перебування у вічному «тепер».

\footnotetext{
${ }^{1}$ Кяманча - східний народний струнний смичковий інструмент. Розповсюджений у Вірменії, Азербайджані, Греції, Грузії, а також у країнах Середнього та Ближнього Сходу. Кяманча - обов'язковий інструмент в ансамблях професійної традиційної музики Сходу. Використовується також як сольний інструмент.
} 
Цей стан є домінуючим. Він утримується однорідними, континуальними тривалостями, які довго тягнуться. Можна припустити, що головною творчою ініціативою розгортання $\epsilon$ моделювання сучасними мовними засобами особливої звукової атмосфери - національної архаїки, відголосків культури, що живуть в уяві композитора.

Друга фаза є наймасштабнішою в симфонії. Тут включається дієве начало i, попри велику кількість остинатних повторів, у ній ясно відчувається векторність музичного розвитку.

У другій фазі настає новий етап кристалізації теми симфонії (звучить у фаготів). Інтонаційно вона вже більш організована, є «точки» початку i завершення, є помітна синтаксична межа (iі можна зафіксувати в момент повторення теми). До того ж композитор варіантно змінює іiі тематичну й ритмічну структуру. Розвиток фази протікає завдяки поліфонічній роботі 3 даним інтонаційним зерном через його стретне накладення. Отже, композитор обирає поліфонічну модель як основний принцип композиційного вибудовування другої фази, причому проеціює їі, зокрема, на ті компоненти оркестрової тканини, для яких подібний тип розвитку не є характерним (наприклад, на ударну групу).

Третя фаза - це епіцентр усієї симфонії, ментально-духовний пік східної рефлексії, виражений «вірменським музичним діалектом». Це так зване «слово автора», глибокий i відвертий монолог, який озвучено тембром кяманчі. Цього разу ефект медитативності пов'язаний не стільки 3 підкресленою роллю тривалого звуку, скільки 3 іще більш ясно відчутним зверненням композитора до монодичних джерел народної вірменської музики.

Третя фаза є серцевиною процесу інтонаційного становлення основної теми симфонії, яка врешті-решт набуває рельєфності й чіткої структурної оформленості. I, звичайно, головним устоєм тут є звук as. Треба зауважити, що характер монодії не перевтілює ії в суто етнографічний елемент - це не зображення, а скоріше глибокий і багатозначний символ, наділений рисами національної монодичної традиції.

Четверта фаза має сигнальну жанрову природу й знову спрямовує весь розвиток у русло дієвості. Тихі інтонації кяманчі поступово «розчиняються» й переходять у категорію «вічне», а різкі гласи труб повертають слухача до буття реальності.

У кульмінації фази - грандіозному передзвоні на fffff, який реконструюється симфонічними засобами (дерев'яні духові та ударні інструменти) i посилюється автентичним звучанням, записаним на магнітофонну плівку - ударна група заміщується континуальною «смугою» у струнних, які вносять просвітлення в загальне звучання фази. 
Інтервальна структура звукового поля базується на тризвуку $C$-dur, який для А. Тертеряна є символом чистоти, гармонії звуків світобудови (як і в Четвертій симфонії). На цьому фоні $з$ домінуючою прогресією декілька разів у кяманчі відлунням звучить звук as. Треба зауважити, що «загорнутий» в ореол $C$-dur, він звучить так само органічно, як i в одноголосному викладі. Тут проявляється ставлення до звука як до світу, як до світла, в якому, в результаті, зникає вся густота дисонансів.

У заключних тактах звукова аура симфонії поступово тане, інструменти «вимикаються». Тритонові «згустки» розв'язуються в тризвук $C$-dur, створюючи акустично чисту педаль, яка вслід за стихаючим голосом кяманчі йде у безкінечність.

Космічне й земне, реальне й ірреальне, сьогоденне та минуле такими в цілому видаються контури драматургічного задуму Шостої симфонії (1981), яка в метафоричній формі передає ідею Вселенської служби, де всі ці світи перетинаються між собою. У даному творі композитор звернувся до екстрамузичних знаків вірменської культурної історії - старовірменського алфавіту грапару й, на відміну від попередніх симфоній, органічно синтезував універсальність художнього переживання й національні символи, які відкривають наново вічний сенс у початкових словах, складах, фонемах великого культурного минулого.

Шоста симфонія - це ідея вічної пам'яті про всіх людей, виражена, насамперед, через духовний зв'язок із ними. Композитор не раз відзначав, що для нього цей зв'язок здійснюється через Бога. Тому в симфонії виникає апеляція до особливої музичної символіки духовних жанрів:

1. Тертерян включає в партитуру тембр людського голосу, завдяки якому з хаотичного говору організується потік храмового псалмодіювання й звучання поступово переростає в молитовний спів. Респонсорні переклички хорових масивів уособлюють діалог між голосами живих i померлих, між світом реальним та потойбічним.

2. Композитор знову звертається до тембру дзвонів (відтворюється автентичне звучання дзвону, записане на магнітофонну стрічку) як до носія сакральної атмосфери, сигналу, що закликає до молитви, голосу космічної гармонії, знаку соборності всесвіту. До цієї групи символів належить i тембр клавесина, що має для Тертеряна значення чогось вищого, вічного, «абсолютного».

3. Тертерян використовує елементи інтонаційної символіки - у симфонії присутній ледь прокреслений мотив хреста, причому в різних варіантах - 3 висхідною й низхідною інтонаціями. Поява даної символіки в творі має важливе смислове навантаження, наповнює його конкретною 
духовною програмою, що відбиває ідею переходу в інший світ, який знаходиться за звичною межею. Важливим аргументом для висування цієї гіпотези є згадка про символ хреста в інтерв’ю самого композитора: «У Шостій симфонії виражено й ідею хреста, кінці якого йдуть у минуле й майбутнє, розходяться вгору i вниз, i в цьому єдність горизонталі й вертикалі. У такій єдності я бачу вираз суті цілісного буття - це й сьогодні, і вчора, а може, і завтра: це народження, але це й кінець» [8, с. 114-115].

Ідея часу, який немов завмер у нескінченності своєї «метафізичної форми», є відправною точкою в розумінні специфічно сконструйованого драматургічного плану твору. Усі рівні музичної драматургії: семантичний підтекст інтонаційних процесів, темброво-мелодичні лінії, кожен елемент незвичайного складу оркестру й фонограми - по-своєму створюють образсимвол часу, який зупинився на межі світів. Ця грань - нульова точка координат, де звукові сфери різних систем отримують можливість доторкнутися, почути голоси й шепіт один одного. Справа не тільки в діалозі, їх поєднанні в якомусь вселенському хорі, але й у тому, що ми (слухачі) відчуваємо свою «включеність» у цей процес.

Композиційно Шосту симфонію можна поділити на три фази. Причому, вперше А. Тертерян застосовує в одночастинній симфонії принцип репризності.

Перша фаза, як це часто буває в одночастинних симфоніях А. Тертеряна, $є$ своєрідним зануренням у медитативний стан. Композитор застосовує вже традиційний для нього прийом почергового включення голосів, які поступово розширюють звукове поле й ніби проявляють ірреальний світ.

Перша фаза вибудовується за принципом статичної драматургії, яка не дає інтонаційного розвитку образного плану, а збагачує його звуковими символами, сонорними шарами, які виникають у процесі розгортання фази. Основним композиційним двигуном тут $є$ поступове широтне потовщення звукового поля, де кожен новий елемент або цілий комплекс елементів нарощуються на каркас із сонорної смуги у струнних інструментів. Важливе значення у становленні такої драматургії відіграє підключення й зняття записаних фонограм - вони не несуть будь-якої динамічної, дієвої енергії, тому що завжди залишаються незмінними.

У другій фазі, після довгого блукання в різнорідних інтонаційних коридорах вселенської «пам'яті», звукова сфера переходить у хор «неживих» голосів, який починає зі слухачем свій діалог. Процесуальний рух хорового тембру від розмитих обрисів фонограмного звучання у крайніх розділах форми приходить до яскраво вираженого звукового образу. 
Завдяки мелодиці хорового виголошення, заснованій на скандуванні букв старовірменського алфавіту ${ }^{1}$, друга фаза має ритуальну природу, яка походить від храмового псалмодіювання. Це впливає на загальний емоційний тонус фази - він суворо-урочистий, натягнутий, напружений.

Несподівано хорова «ідилія» обривається потужною, одноплановостатичною i багаторазово повторюваною «навалою» тембру мідних духових. Важка механічна хода однозначно підпорядковує собі всі супутні інтонаційно-звукові пласти, які включають речитацію хором букв вірменського алфавіту й сонорний пласт струнних. У результаті стикаються два абсолютно протилежні плани: сувора «молитва» хору з їі рішучістю й мужністю накладається на грубий інструментальний імператив. Антитеза «живе-неживе», «людське-антигуманне» народжує суперечливе враження: хор ніби не може наблизитись до характеру фонограми, а остання не зливається з емоцією співу-речитації.

Досягнувши максимальної потужності, спів слабшає й поступово зникає - «усе повертається на круги своя, у простір прачасу» [7, с. 342]. Так розвиток симфонії переходить у третю фазу. Знову наступає звуковий хаос, з якого народжувалися голоси всесвіту. Тому в третю фазу повертаються деякі інтонаційні компоненти з першої.

Завершується симфонія Мі-мажорним тризвуком - заключним акордовим імпульсом, що «спалахує» в оркестрі на раптовому forte. Звучання симфонії поступово розчиняється у звуковому ефірі композитор залишає діалог відкритим: «Просвітлений E-dur, який з'являється наприкінці симфонії, ніби відкриває перед тобою ще одну, останню завісу, і ти входиш туди, де залишаються тільки далекі передзвони, як явища минулого життя, минулих земних станів. Дзвони... ти перестаєш їх чути в міру того, як віддаляєшся в нескінченну тишу. I за нею, напевно, існує нова ієрархія станів нескінченного світу, яку ми просто не знаємо, для нас тиша - це остання точка відліку» [8, с. 117].

Висновки. Етап становлення вірменської національної симфонічної музики, пов'язаний з ім'ям Авета Рубеновича, є одним із ключових у загальному контексті розвитку жанру і за значенням його можна порівняти 3 досягненнями Комітаса, О. Спендіарова, А. Хачатуряна та інших класиків музичного мистецтва Вірменії. Справедливо буде стверджувати, що саме завдяки А. Тертеряну вірменська симфонія вийшла за рамки класичної моделі жанру i, збагатившись сучасною композиторською мовою, поіншому розкрила особливу національну природу вірменської музики.

\footnotetext{
${ }^{1}$ «Співаються букви вірменського алфавіту, які мають виключно сонорне значення» (позначка композитора у партитурі).
} 
Індивідуальний стиль А. Тертеряна представляється як багатогранний, складний візерунок сплетених разом жанрів східного мистецтва - давньої й самобутньої традиції вокального та інструментального музикування від вірменської селянської пісні, ашугської імпровізації й духовної гімнографії до буддійського ритуального співу - з їхньою естетикою самодостатнього, виразного звуку, музичною поетикою, відчуттям художнього часу й простору. Цим пояснюється особливе значення монодичної традиції як стрижневого формотворного фактора в багатьох творах А. Тертеряна, зокрема - у симфонічних опусах.

Значення монодії як драматургічного принципу може бути розглянуто й на прикладі ставлення композитора до звуку взагалі. Ідеться про «концепцію одиночного звуку» (М. Рухкян), «ритуал споглядання звуку», в якому монодійність мислення переростає в особливу філософську систему, де все різноманіття явищ розглядається крізь призму одного начала, єдиної основи. Багатобарвність, спектральність, глибина, смислова наповненість - все це Авет Рубенович чує в одному єдиному звуці. У результаті, у стилістичних константах композиторської творчості Тертеряна даний феномен набуває стабільну семантичну характеристику як образ звуку-процесу, який містить у собі цілу концепцію світовідчуття, зв'язок автора 3 космосом, 3 ірреальним світом, 3 ефіром і його інтерпретацію цього величезного естетичного й фізичного простору.

Для подібних новаторських пошуків А. Тертеряна жанр симфонії виявився найбільш благодатним підгрунтям. Проаналізовані П'ята та Шоста симфонії - яскраве тому підтвердження. У них немає традиційних форм-схем, немає контрастних тем, що вступають у «риторичні» взаємодії, але є нове співвідношення елементів, при якому рушійна сила не боротьба різних начал, а внутрішнє зростання образів. Для симфоній Тертеряна практично непридатні поняття тематизм і тематичний розвиток у традиційному сенсі. Специфіка формоутворення в них концентрується в області фоніки, тому, відповідно, - сонорики, яка у взаємодії з тембром, ритмом i фактурою створює композиційну структуру одночастинних симфоній Тертеряна. Композитор віддає перевагу статичним континуальним темброзвуковим зонам i, за зауваженням С. Савенко, такому типовому сонорному виду контрасту, як зіставлення об'ємів звучання (найбільш яскраво цей прийом втілений композитором у його П'ятій симфонії). I в цьому також простежується зв'язок тертерянівського симфонізму 3 фундаментальними властивостями національного художнього мислення. 
Крім сонорної техніки, для побудови композиційного профілю симфоній А. Тертерян звертається й до інших сучасних композиторських технік, які відповідають новому рівню музичної мови творів i специфічному способу їх розвитку, а саме - до алеаторики, додекафонії, мікрохроматики, мікросерійності.

Об'єднуючим фактором для обох симфоній стає єдиний спосіб організації цілого, що втілює принцип одночастинності. I в П’ятій, і в Шостій симфоніях композиція формально не ділиться на розділи, але $є$ неоднорідною в семантико-конструктивному відношенні, тому іiі можна умовно розмежувати на фази драматургічного «проростання» матеріалу.

У П'ятій симфонії первинним імпульсом стає одиночний звук, 3 якого виростає вся звукова матерія твору і в який періодично згортається.

Перша й третя фази твору підпорядковані мелодико-тембровому пласту, де звук, його колористичне й сонорне оточення панують. Тут основу сонорної композиції складає континуальна смуга, звучання якої безперервно триває і складається як комплекс безлічі ліній. У другій i четвертій фазах культ монодії розпадається, включається дієве начало, яке проявляється в симфонії у яскраво вираженій остинатності, превалюванні ритмічного начала, у фактурній щільності оркестрових голосів, провідній ролі низьких мідних та ударних інструментів. У даних фазах збільшується інтенсивність і щільність параметрів сонорного матеріалу, а головною фактурною формою композиційного процесу стає сонорний потік, активно-пульсуюче звучання якого забезпечує «крещендування» форми.

Композиція Шостої симфонії поділяється на три фази. Перша фаза втілює ідею вселенського звукового хаосу й вибудовується за принципом «нарощування» нових тембрів й інтонаційних пластів, які поступово проявляють ірреальний світ. Звуки-символи тут існують майже в повній статиці, в тривалому спогляданні-медитації і тим самим створюють інерцію, яка притупляє відчуття звичного плину часу. Досягаючи кульмінації, розвиток переходить у другу фазу - хаос організовується у всесвітній хорсуворе храмове псалмодіювання «неживих» голосів, які вступають у діалог iз реальним світом. Досягнувши максимальної згоди, у третій фазі спів слабшає і поступово зникає, у музичній тканині з'являються інтонації 3 першої фази, усе ніби замикається, повертається у простір прачасу й розчиняється у Мі-мажорному акорді, який завершує симфонію.

Не дивлячись на те, що в обох симфоніях остання фаза драматизується, композитор все одно приводить іiі звучання до просвітління через включення акустично чистого мажорного тризвуку. В аурі цього акорду розсіюється вся густота дисонансів, звучання набуває 
нематеріальної природи. Незмінність позитивного закінчення симфоній характеризує естетичну векторність авторського світогляду 3 його тяжінням до світлого начала. Це багато в чому пов’язано 3 гуманістичними, філософсько-теологічними ідеями Тертеряна - яких би драматичних висот не досягав композитор, відображаючи у своїх полотнах вселенський хаос, катаклізми, втрату людських цінностей, він завжди дарує в кінці просвітлення, катарсис за допомогою консонантних мажорних співзвуч, які виникають у драматургічних розв'язках його партитур: Подібного висновку приходить i Рубен Тертерян, син композитора, висловлюючись про феномен музики Авета Тертеряна: «Творчість Тертеряна духовна в спрямованості до Бога, проте глибоко гуманістична в спрямованості до Людини, яка не зламана, яка не принижена страхом, а піднесена вірою...» [8, с. 254].

1. Арановский М. Г. Симфонические искания. Москва : Сов. композитор, 1979. 288 с.

2. Ковбас И. Г. Диалектика медитативности и действенности в современной симфонической драматургии (на материале советской симфонии 60-80-х годов) : автореф. дис. ... канд. искусствоведения : спец. 17.00.02 «Музыкальное искусство» / Киевская гос. конс. им. П. И. Чайковского. Киев, 1991. 20 с.

3. Кузнецова М. И. Медитативность как свойство музыкального мышления (Авет Тертерян, Арво Пярт, Валентин Сильвестров): автореф. дис.... канд. искусствоведения : спец. 17.00.02 «Музыкальное искусство» / Московская гос. конс. им. П. И. Чайковского. Москва, 2007. 26 с.

4. Маклыгин А. Л. Фактурные формы сонорной музыки// Laudamus. Москва : Композитор, 1992. С. 129-137.

5. Птушко Л. А. Стиль симфоний Авета Тертеряна : автореф. дис. ... канд. искусствоведения : спец. 17.00.02 «Музыкальное искусство»/ Нижегородская гос. консерватория им. М. И. Глинки. Нижний Новгород, 1994. 18 с.

6. Рухкян М. А. Авет Тертерян. Творчество и жизнь. Ереван : Наири, 2002. 248 с.

7. Савенко С. И. Авет Тертерян: путь к глубинам звука // Музыка из бывшего СССР : сб. ст. Вып. 2. Москва : Композитор, 1996. С. 320-333.

8. Тертерян Р. А. Авет Тертерян. Диалоги. Ереван : Издательство ЕГК, 2010. 284 с.

9. Холопов Ю. Н. Гармония. Практический курс : учебник для специальных курсов консерваторий (музыковедческое и композиторское отделения): в 2 частях. Часть II. Москва : Композитор, 2005. 613 с.

10. Klemm E. Avet Terterian - musikalischer Seismograph Armeniens. URL: http://www.terterian.org/en/on-avet-terterian/essays/ekkehard-klemm-avet-terterianmusikalischer-seismograph-armeniens/ (berufungsdatum: 24.01.2017).

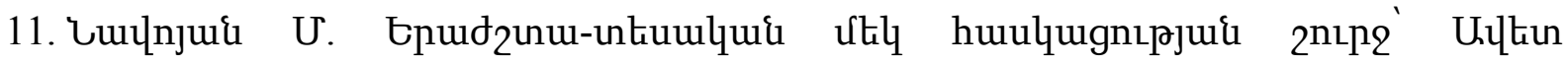

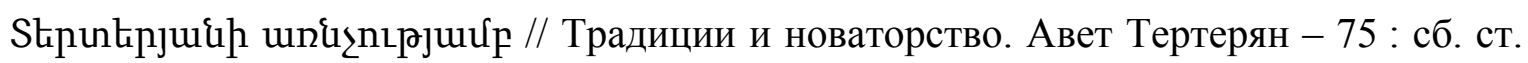
Ереван : Арджеш, 2005. С. 20-26. 


\section{References}

1. Aranovskiy, M. (1979). Symphonic searches. Moscow: Sovetskiy kompozitor [in Russian].

2. Kovbas, Y. (1991). The dialectic of meditativeness and effectiveness in modern symphonic dramaturgy (based on the material of the Soviet symphony of the 1960s and 1980s). Extended abstract of $\mathrm{PhD}$ thesis. Kyiv [in Russian].

3. Kuznetsova, M. (2007). Meditativeness as a property of musical thinking (Avet Terteryan, Arvo Pärt, Valentin Silvestrov). Extended abstract of PhD thesis. Moscow [in Russian].

4. Makligin, A. (1992). Textural forms of sonorous music. Laudamus. Moscow: Kompozitor, pp. 129-137 [in Russian].

5. Ptushko, L. (1994). Avet Terteryan's symphony style. Extended abstract of $\mathrm{PhD}$ thesis. Nizhniy Novgorod [in Russian].

6. Ruhkyan, M. (2002). Avet Terteryan. Creativity and life. Yerevan: Nairiy [in Russian].

7. Savenko, S. (1996). Avet Terteryan: path to the depths of sound. Muzyka iz byvshego SSSR, 2, pp. 320-333 [in Russian].

8. Terteryan, R. (2010). Avet Terteryan. Dialogues. Yerevan: YEGK [in Russian].

9. Kholopov, Y. (2005). Harmony. Practical course. Vol. 2. Moscow: Kompozitor [in Russian].

10. Klemm, E. (1999). Avet Terteryan - musical seismograph of Armenia [online]. Available at: http://www.terterian.org/en/on-avet-terterian/essays/ekkehard-klemm-avet-terterianmusikalischer-seismograph-armeniens/ [Accessed 24 January 2017] [in German].

11. Navoyan, M. (2005). About a Musical-Theoretical Concept Concerning Avet Terteryan's Music. Traditsii $i$ novatorstvo. Avet Terteryan - 75. R. Amirhanyan. (Ed.). Yerevan: Ardzhesh, pp. 20-26 [in Armenian]. 